Ritrýnd grein birt 31. desember 2020

\title{
„Núna eru allir einhvern veginn rosa uppteknir og pað er enginn sem svona heldur utan um krakkana": Pörf á foreldrafræðslu: Sýn umsjónarkennara á miðstigi grunnskóla
}

\begin{abstract}
Sigrún Helgadóttir og Hrund Pórarins Ingudóttir
Abract Um höfunda $>$ About the authors $>$ Heimildir

Pær breytingar sem hafa orðið á fjölskyldulífi undanfarna áratugi hafa leitt af sér nýjar áskoranir í uppeldi barna. Pá upplifa margir foreldrar streitu vegna samhæfingar fjölskyldu- og atvinnulífs. Markmið rannsóknarinnar er að varpa ljósi á áskoranir í uppeldi 10-13 ára barna að mati umsjónarkennara. Aukinheldur að skoða sýn peirra á hlutverk og ábyrgð foreldra og umsjónarkennara á uppeldi sem og mat peirra á pörf á stuðningi og uppeldisfræðslu fyrir foreldra. Tekin voru viðtöl við átta umsjónarkennara 5.-7. bekkja í grunnskólum. Helstu niðurstöður eru pær að miklar samfélagslegar kröfur eru gerðar til foreldra sem verða til pess að foreldrar eru mjög uppteknir. Umsjónarkennararnir finna fyrir kröfu frá foreldrum um að peir styðji pá enn frekar en áður við uppeldi barna sinna. Umsjónarkennurunum finnst pað varla vera sitt hlutverk, peir séu hvorki menntaðir til pess né sé peim mögulegt að bæta á sig fleiri verkefnum. Peir vilja að foreldrar beri ábyrgð á og sinni uppeldi barna sinna. Peir telja foreldra 10-13 ára barna hafa pörf á stuðningi og uppeldisfræðslu. Niðurstöður rannsóknarinnar ættu að vera mikilvægt innlegg í umræðu um hlutverk og ábyrgð foreldra og kennara á uppeldi barna. Einnig ættu pær að nýtast við stefnumótun foreldrafræðslu og uppeldisráðgjafar, vera stuðningur fyrir pá sem vinna með foreldrum og með pví vera mikilvægar fyrir foreldra og börn.
\end{abstract}

Efnisorð: Foreldrar, börn, uppeldi, grunnskóli, kennarar, foreldrafræðsla og uppeldisráðgjöf

\section{Inngangur}

Miklar samfélagslegar breytingar hafa átt sér stað á síðastliðnum áratugum sem leitt hafa til nýrra krafna og væntinga til uppeldis (OECD, 2020). Nú á dögum er gerð ríkari krafa til foreldra en áður um að börn peirra séu heilbrigð, örugg, sýni góðan árangur í pví sem pau taka sér fyrir hendur og verði síðar góðir samfélagspegnar (Roskam o.fl., 2017). Svo hægt sé að styðja foreldra er mikilvægt að skoða hvað pað er sem reynir helst á í uppeldi barna. Pessi grein byggist á rannsókn par sem skoðuð var sýn umsjónarkennara á miðstigi grunnskóla á áskoranir í uppeldi og pörf foreldra 10-13 ára barna á stuðningi og uppeldisfræðslu. Börn á miðstigi grunnskóla verja stórum hluta dagsins í skólanum en samkvæmt aðalnámskrá grunnskóla (Mennta- og menningarmálaráðuneyti, 2011) er vikulegur kennslutími barna á pessum aldri rúmir 23 tímar. Pví má ætla að umsjónarkennarar barna i 5.-7. bekk pekki vel til parfa barna á pessum aldri. Einnig má gera ráð fyrir að peir pekki vel til foreldra pessara barna pví grunnskólinn á „í samvinnu við heimilin“ að „stuðla að alhliða proska allra nemenda“ (lög um grunnskóla nr. 91/2008, 2. gr.) og ber hann ábyrgð á samstarfi heimilis og skóla (Mennta- og menningarmálaráðuneyti, 2011). Pví ætti sjónarhorn umsjónarkennara að varpa mikilvægu ljósi á áskoranir í uppeldi barna. Rannsókninni er einnig ætlað að skoða hlutverk og ábyrgð 
foreldra og umsjónarkennara á uppeldi barna sem og pörf foreldra fyrir stuðning og uppeldisfræðslu AĐ mati umsjónarkennara.

\section{Uppeldishlutverkið}

Hér á landi eru í gildi lög og reglugerðir um ábyrgð og skyldur foreldra. Samkvæmt peim bera foreldrar „höfuðábyrgð“ á börnum sínum (lög um samning Sameinuðu pjóðanna um réttindi barnsins nr. 19/2013, 27. gr.) og „,ber að annast barn sitt og sýna pví u mhyggju og virðingu og gegna forsjár- og uppeldisskyldum sínum svo sem best hentar hag barns og pörfum“ (barnalög nr. 76/2003, 28. gr.). Foreldrar skulu einnig búa börnum sínum „viðunandi uppeldisaðstæður og gæta velfarnaðar peirra í hvívetna“" (barnaverndarlög nr. 80/2002, 1. gr.). Pá ber peim að „afla barni sínu lögmæltrar fræðslu“ (barnalög nr. 76/2003, 28. gr.). Foreldrar bera „ábyrgð á námi barna sinna“ (19. gr.) og ber peim að „fylgjast með og styðja við skólagöngu og námsframvindu“ (18. gr.) (lög um grunnskóla nr. 91/2008). Jafnframt bera foreldrar ábyrgð á hegðun barna sinna og eiga peir að bregðast við afleiðingum óæskilegrar hegðunar peirra í skólanum (reglugerð um ábyrgð og skyldur aðila í skólasamfélaginu nr. 1040/2011).

Ljóst er að foreldrahlutverkið er margpætt og pví fylgir mikil ábyrgð. Foreldrar virðast vera meðvitaðir um ábyrgð sína á uppeldi barna sinna en á sama tíma finnst mörgum peirra pessi ábyrgð vera eitt af pví erfiðasta við hlutverkið (Hrund Pórarinsdóttir og Sigrún Aðalbjarnardóttir, 2010). Til að foreldrar geti sinnt hlutverki sínu og ábyrgð sem best er mikilvægt að peir hafi aðgang að ráðgjöf og stuðningi, til dæmis í formi uppeldis- og foreldrafræðslu. Slík fræðsla hefur verið skilgreind sem ferli sem felur í sér aukna færni, innsæi, skilning, viðhorf og pekkingu á proska barna og sambandi foreldris og barns ásamt að stuðla að vexti í foreldrahlutverkinu (NPEN, 2021). Komið hefur fram í fyrri rannsóknum að foreldrar vilja fá stuðning í foreldrahlutverkinu (Birna María Svanbjörnsdóttir, 2007; Hrund Pórarinsdóttir og Sigrún Aðalbjarnardóttir, 2010).

Pegar skoðað er framboð á uppeldisfræðslu, ráđgjöf og stuðningi á Íslandi fyrir foreldra 10-13 ára barna virðist lítið vera í boði fyrir foreldra sem vilja leita sér almennrar fræðslu um uppeldi og fá stuðning til að takast á við daglegar áskoranir foreldrahlutverksins. Meira er í boði pegar upp er kominn vandi. Til dæmis er PMTO (Parent Management Training - Oregon aðferð) meðferðarúrræði fyrir foreldra barna með hegðunarerfiðleika (Margrét Sigmarsdóttir o.fl., 2015). ART-teymið á Suðurlandi (e.d.) er með fjölskyldu-ART (Aggression Replacement Training) par sem foreldrum eru „kenndar leiðir til pess að ná jákvæðum aga og eiga árangursrík og góð samskipti á heimilinu“. Foreldrahús (e.d.), starfsstöð foreldrasamtakanna Vímulaus æska, býður upp á fræðslu, ráðgjöf og úrræði fyrir foreldra peirra barna sem leiðast snemma út í vímuefnavanda. Litla kvíðameðferðarstöðin (e.d.) sem sérhæfir sig í kvíða barna heldur námskeið fyrir foreldra. Hegðunarráðgjöf (2017) býður upp á ráðgjöf og „kennslu til fjölskyldna barna með einhverfu eða önnur proskafrávik“. Sálstofan (e.d.) er með námskeið fyrir foreldra barna sem eiga erfitt með að stjórna skapi sínu. Hjá heilsugæslunni (e.d.) um land allt er verið að innleiða foreldramiðaða meðferð við kvíða hjá börnum á aldrinum 6-12 ára par sem foreldrum eru kenndar aðferðir hugrænnar atferlismeðferðar. Heimili og skóli (e.d.) eru með fræðslu og fyrirlestra um pætti sem lúta að samstarfi heimilis og skóla. Auk pessa má finna mikið af uppeldisráðum á veraldarvefnum, í hlaðvörpum og fleira en erfitt getur verið fyrir foreldra að átta sig á gæðum upplýsinganna (OECD, 2020). Til að mennta fólk, sérhæft í að veita fjölbreyttum hópi foreldra almenna fræðslu og stuðning í uppeldishlutverkinu, hefur Háskóli Íslands boðið upp á MA-nám í foreldrafræðslu og uppeldisráđgjöf frá haustinu 2015 og diplómu frá 2021 (Háskóli Íslands, e.d.-b). Fyrstu nemendurnir hafa útskrifast og eru að stíga sín fyrstu skref á vettvangi foreldrafræðslu og uppeldisráðgjafar.

Kennarastéttin kemur einnig að uppeldi barna en henni ber, samkvæmt aðalnámskrá grunnskóla (Mennta- og menningarmálaráðuneyti, 2011), að sinna kennslu, stjórnun, uppeldi, ráðgjöf, rannsóknum og próunarstarfi. Pá ber umsjónarkennari ábyrgð á námi, proska, „líðan og velferð“ nemenda sinna (Mennta- og menningarmálaráðuneyti, 2011). Kennarar skulu „rækja starf sitt af fagmennsku, alúð og samviskusemi“ og „gæta kurteisi, nærgætni og lipurðar í framkomu sinni gagnvart börnum, 
[og] foreldrum peirra“ (lög um grunnskóla nr. 91/2008, 12. gr.). Kennarar vilja eiga góð samskipti við nemendur og foreldra peirra (Sigrún Erla Ólafsdóttir og Sigrún Aðalbjarnardóttir (2013). Peir virðast standa sig vel pví að mati nemenda í 6 . bekk er kennurum annt um nemendur sína og hægt að treysta peim (Einar B. Porsteinsson og Ársæll Arnarsson, 2018). Í námi grunnskólakennara er eitthvað komið inn á foreldrasamstarf og tengsl heimilis og skóla í nokkrum námskeiðum en pó mismikið (Háskóli Î́slands, e.d.-a, Háskólinn á Akureyri, e.d.).

Grunnskólakennarar finna fyrir álagi í starfi. Samkvæmt nýrri rannsókn (Sif Einarsdóttir o.fl., 2019) hefur kulnun meðal kennara aukist og helsta ástæðan talin ofálag; of mörg verkefni, tímapressa og mikil persónuleg samskipti við nemendur. Að auki hefur komið fram að hegðunarerfiðleikar nemenda leiða til tilfinningaprots kennara (Snæfríður Dröfn Björgvinsdóttir og Anna-Lind Pétursdóttir, 2014). Lengi hafa kennarar upplifað hegðun nemenda á miðstigi grunnskóla erfiða, samanber niðurstöður rannsóknar frá 2006 (Ingvar Sigurgeirsson og Ingibjörg Kaldalóns). Pá töldu kennarar að rekja mætti erfiða hegðun nemenda til „óheppileg[ra] uppeldisaðferð[a]“ foreldra, svo sem skorts á ramma og tímaleysi. Samkvæmt nýlegri rannsókn (Ragnar F. Ólafsson, 2019) fer meiri tími í agamál í kennslustofunni á unglingastigi hér á landi en á hinum Norðurlöndunum. Kennurum finnst erfiðara en áður að setja nemendum mörk samkvæmt skýrslu Skúla Helgasonar og félaga (2017). Par kemur einnig fram að kennurum finnst erfið foreldrasamskipti valda álagi í starfi. Kennarar telja að hægt væri að draga úr álagi á pá með pví að auka aðgengi að öðrum sérfræðingum (Skúli Helgason o.fl., 2017).

Umsjónarkennarar upplifa aukinn prýsting frá foreldrum um að peir sjái um ýmsa uppeldislega pætti sem voru áđur á hendi heimilanna (Erla Sif Markúsdóttir og Lilja M. Jónsdóttir, 2016; Skúli Helgason o.fl., 2017). Aftur á móti óska kennarar eftir pví að foreldrar axli aukna ábyrgð á uppeldi barna sinna og telja að ekki sé nóg að leik- og grunnskólar komi að uppeldi barna (Ingvar Sigurgeirsson og Ingibjörg Kaldalóns, 2006). Peir telja að foreldrar purfi að huga að gildismati sínu og forgangsröðun og verja meiri tíma með börnum sínum (Ingvar Sigurgeirsson og Ingibjörg Kaldalóns, 2006). Kennarar telja foreldra forgangsraða tómstundum barna sinna fram yfir heimanám (Skúli Helgason o.fl., 2017). Pá vilja kennarar að foreldrar komi meira inn í skólann en telja á sama tíma að foreldrar hafi ekki pann tíma aflögu (Nanna Kristín Christiansen, 2011). Uppeldisaðferðir og stuðningur foreldra við nám barna sinna geta skipt miklu máli fyrir námsárangur peirra (Alonso o.fl., 2017; Sigrún Aðalbjarnardóttir, 2019).

\section{Uppeldi í nútímasamfélagi}

Í nútímasamfélagi hafa margir pættir áhrif á foreldrahlutverkið. Kröfur eru gerðar til foreldra um atvinnupátttöku en Ísland er meðal peirra landa OECD par sem hún er hæst (OECD, e.d.). Foreldrar finna líka fyrir streitu vegna samhæfingar fjölskyldu- og atvinnulífs (Andrea Hjálmsdóttir og Marta Einarsdóttir, 2019; Kolbeinn H. Stefánsson, 2008). Foreldrar nefna að langir vinnudagar og heimilisstörf vegi pungt í upplifun peirra á streitu, ásamt barnauppeldi, sér í lagi tómstundaiðkun barna, heimanámi og öðru samstarfi sem snýr að skólagöngu barna (Andrea Hjálmsdóttir og Marta Einarsdóttir, 2019). Pó að um helmingur foreldra telji sig hafa nægan tíma fyrir barn sitt samkvæmt rannsókn Hrundar Pórarinsdóttur og Sigrúnar Aðalbjarnardóttur (2010) er um priðjungur ekki á pví máli og sama hlutfall talar um tímaskort í uppeldishlutverkinu. Rúmlega $80 \%$ barna og ungmenna segjast eiga góð eða mjög góð samskipti við foreldra sína (Ársæll Már Arnarsson o.fl., 2020). Góð samskipti foreldra og barna er verndandi páttur í uppeldi barna pví pau stuðla að jákvæðum félagslegum gildum sem hjálpa ungu fólki að takast á við krefjandi aðstæður (WHO, 2012). Mikilvægi samveru foreldra og barna hefur komið fram í rannsóknum (Sigrún Aðalbjarnardóttir, 2019; Steinberg, 2001). Leiðandi uppeldishættir (Baumrind, 1971) eru taldir hvað heillavænlegastir par sem foreldrar sýna börnum sínum mikla hlýju og uppörvun en á sama tíma setja peim skýr mörk. Pessir foreldrar nota útskýringar, hvetja börnin til að skýra út sín sjónarmið, taka vel á móti hugmyndum peirra og krefjast proskaðrar hegðunar af peim. Börn sem alast upp við leiðandi uppeldishætti sýna almennt meiri samskiptahæfni, betri námsárangur, betra sjálfsálit, minni depurð og eru ólíklegri til að neyta vímuefna en börn sem alin eru upp við aðra uppeldishætti (Sigrún Aðalbjarnardóttir, 2019). 
Á Íslandi er hefð fyrir pví að börn njóti mikils frelsis í uppeldi (Jóhanna Einarsdóttir, 2006). Skortur er á rannsóknum á pessu sviði en samkvæmt doktorsrannsókn Baldurs Kristjánssonar (2001) virðast íslenskir foreldrar setja sig minna inn í líf barna sinna samanborið við hinar norrænu pjóðirnar.

Börn á aldrinum 10-13 ára verja stórum hluta dagsins í skólanum. Stór hluti 6. bekkinga segist að sér líki mjög vel (43\%) eða pokkalega (48\%) í skólanum en rúmur priðjungur segist pó finna fyrir nokkru eða miklu álagi vegna skólanámsins (Einar B. Porsteinsson og Ársæll Arnarsson, 2018). Íprótta-, félags- og tómstundastarf skipar stóran sess í lífi margra barna á pessum aldri. Um helmingur peirra tekur reglulega pátt í slíku starfi og stór hluti peirra sem stunda ípróttir æfir eða keppir allt að fimm sinnum í viku (Margrét Lilja Guðmundsdóttir o.fl., 2020). Íprótta-, félags- og tómstundastarf barna getur haft jákvæð áhrif á margvíslegan proska peirra (Vandell o.fl., 2019). Ýmislegt getur pó haft áhrif á að börn hætti pátttöku, eins og kostnaður, tímaleysi, dvínandi áhugi og of mikil samkeppni (Hrefna Pálsdóttir o.fl., 2011).

Félagsproski barna á pessu aldursskeiði er í mikilli mótun (Collins og Madsen, 2019). Hér á landi segist stór hluti nemenda í 5.-7. bekk eiga marga vini í skólanum, en $8 \%$ nemenda segjast eiga enga eða fáa vini og 13\% segjast finna stundum eða oft fyrir einmanaleika (Margrét Lilja Guðmundsdóttir o.fl., 2020). Um 6\% nemenda í 6. bekk segjast vera lagðir í einelti einu sinni í viku eða oftar (Einar B. Porsteinsson og Ársæll Arnarsson, 2018). Einhver aukning hefur verið undanfarin ár á að börn í 5.-7. bekk verði fyrir stríðni á netinu en 2019 sögðust 6\% stúlkna og 4\% drengja verða fyrir slíku (Margrét Lilja Guðmundsdóttir o.fl., 2020) og rúmlega 10\% barna segjast verða fyrir neteinelti (Páll Biering og Guðberg K. Jónsson, 2016).

Streita hefur áhrif á andlega heilsu og líðan barna (Crnic og Coburn, 2019). Rúmur priðjungur nemenda í 6. bekk segist fá höfuðverk vikulega eða oftar og um fimmtungur segist finna fyrir depurð vikulega eða oftar (Einar B. Porsteinsson og Ársæll Arnarsson, 2018). Tíðni daglegrar depurðar er 4\% meðal drengja og 8\% meðal stúlkna í 6. bekk (Ársæll Arnarsson, 2019). Pegar litið er til leiða nemenda í 5.-7. bekk segjast á bilinu 11-13\% drengja og 10-19\% stúlkna finna stundum eða oft fyrir leiða á síðustu 7 dögum (Margrét Lilja Guðmundsdóttir o.fl., 2020). Pá sýndu um 16\% barna í 6. og 7. bekk einkenni ofsakvíða, 7\% almennrar kvíðaröskunar og 20\% aðskilnaðarkvíða, í lítilli rannsókn (69 pátttakendur) sem gerð var í tveimur grunnskólum 2016 (Brynja Örlygsdóttir o.fl.).

Margt getur stuðlað að streitu í nútímasamfélagi, svo sem tölvu- og snjalltækjanotkun (Barr, 2019), en stór hluti íslenskra barna telst virkir notendur (Jóna Karen Sverrisdóttir o.fl., 2013; Margrét Lilja Guðmundsdóttir o.fl., 2020). Stafræni heimurinn felur í sér ýmis tækifæri en á sama tíma áskoranir (Barr, 2019). Komið hefur fram að minni skjátími og meiri hreyfing hjá unglingum minnkar líkur á punglyndi, kvíða, lágu sjálfsmati og lífsleiða (Soffía M. Hrafnkelsdóttir o.fl., 2018; Twenge og Campbell, 2018). Einnig tengist mjög mikil notkun samfélagsmiðla daglegri depurð barna og unglinga (Ársæll Arnarsson, 2019). Pá eru tengsl milli net- og skjánotkunar barna og svefntruflana (Lemola o.fl., 2015). Unglingum finnst pað vera hlutverk foreldra sinna að setja mörk um netnotkun (Ólína Freysteinsdóttir o.fl., 2015), en spurning er hvort foreldrar séu að sinna pví hlutverki pví um 38\% evrópskra barna á aldrinum 9-13 ára eru á samfélagsmiðlum prátt fyrir að aldurstakmarkið sé 13 ára (Livingstone o.fl., 2011). Pá er einnig spurning hvort foreldrar hafi nægjanlega pekkingu á netnotkun barna sinna en um 19\% íslenskra foreldra segjast ekki pekkja netnotkun barna sinna mjög vel (Jóna Karen Sverrisdóttir o.fl., 2013). Foreldrar purfa að leiðbeina börnum sínum pegar kemur að tölvu- og snjalltækjanotkun (Barr, 2019) en erlendis hefur komið fram að foreldrar vilja fá fræðslu og stuðning frá skólum barna sinna varðandi skjánotkun (Livingstone o.fl., 2015).

Af pessu má sjá að bæði foreldrar og kennarar hafa skyldum að gegna í uppeldi barna pó foreldrar beri meginábyrgðina lögum samkvæmt. Foreldrum finnst ábyrgðin erfið, finna fyrir streitu vegna samhæfingar fjölskyldu- og atvinnulífs og vilja fá stuðning í uppeldishlutverkinu. Umsjónarkennarar pekkja vel til daglegs lífs barna og pví er mikilvægt að fá sjónarhorn peirra á pörf fyrir fræðslu og stuðning við foreldra. Pví verður hér leitað svara við eftirfarandi rannsóknarspurningum: Hvaða áskoranir fylgja uppeldi 10-13 ára barna að mati umsjónarkennara? Hvert er hlutverk og ábyrgð foreldra og umsjónarkennara á uppeldi barnanna? Hver er pörf foreldra á stuðningi og uppeldisfræðslu að mati umsjónarkennaranna og hvaða viðfangsefni purfa foreldrar helst að fá fræðslu um? 


\section{Аðferð}

Til að leita svara við rannsóknarspurningunum voru tekin átta hálfopin viðtöl við umsjónarkennara á miðstigi grunnskóla sem síðan voru pemagreind (Braun og Clarke, 2006). Rannsóknin er meistaraverkefni fyrri höfundar pessarar greinar en hún er hluti af stærra rannsóknarverkefni sem seinni höfundur stendur fyrir og leiðir um pörf foreldra fyrir fræðslu og stuðning í uppeldishlutverkinu.

Pátttakendur voru valdir af hentugleika (Braun og Clarke, 2013). Leitast var við að pátttakendur væru fjölbreyttir hvað varðar búsetu, kyn, aldur og starfsaldur til að stuðla að gæðum rannsóknarinnar. Allir pátttakendur störfuðu sem umsjónarkennarar á miðstigi grunnskóla og höfðu allir leyfisbréf sem grunnskólakennarar. Prír peirra kenndu 5. bekk, prír 6. bekk og tveir 7. bekk. Fimm peirra höfðu lokið námi frá Kennaraháskóla Íslands á peim árum sem kennaranámið var prjú ár og tveir peirra höfðu síðar lokið meistaranámi. Hinir prír höfðu lokið háskólanámi í öðrum greinum áður en peir bættu við sig kennararéttindum. Pátttakendur voru á aldrinum 32-61 árs, sjö konur og einn karl. Starfsaldur peirra í grunnskóla var 3-32 ár. Fjórir pátttakenda bjuggu og störfuðu í Reykjavík, í premur mismunandi hverfum. Í Reykjavík eru meðaltekjur 590 p.kr. á mánuði (Hagstofa Íslands, e.d.-b). Tveir pátttakenda bjuggu og störfuðu í dreifbýli par sem meðaltekjur á hvorum stað eru rétt rúmar 500 p.kr. (Hagstofa Íslands, e.d.-b) og tveir pátttakendur í sjávarporpi par sem meðaltekjur eru annars vegar rúmar 500 p.kr. og hins vegar rúmlega 600 p.kr. (Hagstofa Î́slands, e.d.-b). Allir pátttakendur nema einn unnu hjá sveitarfélagi par sem innflytjendur voru meðal nemenda (Hagstofa Íslands, e.d.-a). Allir pátttakendur nema einn voru sjálfir foreldrar og áttu eitt til fimm börn. Öll viðtölin voru tekin á vinnustöðum pátttakenda fyrir utan eitt sem var tekið á heimili pátttakanda. Viðtölin voru á bilinu 35-90 mínútur að lengd. Í viðtölunum var stuðst við viðtalsvísi. Hann byggði að hluta til á vísi sem gerður var fyrir stærri rannsóknina en spurningum var bætt við og pær lagaðar að pátttakendum pessarar rannsóknar. Viðtalsvísirinn var forprófaður í æfingaviðtali áður en rannsókn hófst. Fyrri höfundur tók viðtölin en hún er menntaður uppeldis- og menntunarfræðingur, með kennsluréttindi í grunn- og framhaldsskóla auk pess sem hún hefur lokið meistaranámi í foreldrafræðslu og uppeldisráðgjöf. Hún hefur yfir 10 ára reynslu af pví að starfa í grunnskóla, meðal annars sem umsjónarkennari á miðstigi. Pá er hún móðir tveggja barna á grunnskólaaldri. Bakgrunnur hennar var gagnlegur fyrir rannsóknina par sem hún hafði innsýn í störf umsjónarkennara og pekkti foreldrahlutverkið af eigin raun.

Farið var í einu og öllu eftir siðareglum Háskóla Íslands (2019) og lögum um persónuvernd og vinnslu persónuupplýsinga (nr. 90/2018). Pátttakendur veittu upplýst sampykki fyrir pátttöku og vinnslu gagna. Peim voru gefin dulnefni við afritun og pess gætt að ekki yrði hægt að rekja neinar persónugreinanlegar upplýsingar til peirra. Viðtölin voru afrituð orðrétt. Við greiningu viðtalanna var pemagreining Braun og Clarke (2006) notuð. Viðtölin voru lesin ítarlega og kóðuð (Clarke o.fl., 2015). Síðan var gerð tillaga að pemum út frá kóðunum og pau borin saman við rannsóknarspurningarnar. Lokapemun mynda síðan svör við rannsóknarspurningunum.

\section{Niðurstöður og umræður}

Greind voru prjú meginpemu: (1) Miklar samfélagslegar kröfur eru gerðar til foreldra og barna, (2) aukin krafa frá foreldrum um að kennarar komi meira að uppeldi barna og (3) pörf á aukinni uppeldisfræðslu og stuðningi fyrir foreldra. Pemagreiningin er undirbyggð með vísun í gögnin og jafnóðum sett í samhengi við fyrri rannsóknir.

\section{Miklar samfélagslegar kröfur eru gerðar til foreldra og barna}

Öllum umsjónarkennurunum var tîðrætt um pær kröfur sem peir upplifa að íslenskt samfélag geri til foreldra og barna. Peir töluðu um mikinn hraða í samfélaginu og tímaskort sem veldur streitu og álagi hjá foreldrum og börnum. Dagskrá foreldranna er pétt og pað bitnar á börnunum að mati umsjónarkennaranna, eða eins og Snæfríður sagði: „Núna eru allir einhvern veginn rosa uppteknir og pað er enginn sem svona heldur utan um krakkana og allt á svo miklum hraða og reddingar.“ 
„Núna eru allir einhvern veginn rosa uppteknir og pað er enginn sem svona heldur utan um krakkana“:

Pörf á foreldrafræðslu: Sýn umsjónarkennara á miðstigi grunnskóla

Umsjónarkennararnir töldu pennan hraða og miklu kröfur verða til pess að foreldrahlutverkið væri flóknara nú en ádur.

Margir peirra töldu að kröfur atvinnulífsins ættu stóran pátt í hraðanum og álaginu á fjölskyldur. Peir vildu meina að atvinnurekendur gerðu „rosalega miklar kröfur ... til foreldra“ (Margrét), „vinnutíminn [væri] of langur“ (Sunna) og með pví yrði samfélagið „ófjölskylduvænt“ (Margrét). Sunna sagðist hafa miklar áhyggjur af áhrifum langs „vinnudag[s foreldra] frá börnunum sínum“ á tengsl foreldra og barna og fannst petta hálf „,vonlaus framtíðarsýn“. Aðrir tóku dæmi um vetrarfríin í skólunum. Pá sæju sumir foreldrar sér ekki fært að taka frí frá vinnu og vissu pví ekki hvað peir ættu „að gera við börnin“ (Puríður). Umsjónarkennararnir bentu á að prátt fyrir innleiðingu vetrarfrís í skólum væri atvinnulífið „alltaf [með] sömu kröfurnar á foreld rana pannig að börnin eru orðin svolítil byrði á foreldrunum“ (Puríður). Að peirra mati væri „samfélagið ... ekki [að] styðja við fjölskyldu- og barnafólk ... [og látið eins og] pað fari allt á hlið ef foreldrar purfa að vera heima“ með börnum sínum (Snæfríður). Petta mat peirra samræmist fyrri rannsóknum sem hafa sýnt að foreldrar eiga erfitt með að samræma fjölskyldu- og atvinnulíf (Andrea Hjálmsdóttir og Marta Einarsdóttir, 2019; Kolbeinn H. Stefánsson, 2008). „Samfélagið parf að aðlagast ... [og] gera foreldrum ... kleift að sinna börnum sínum,“ sagði Puríður.

Рað er ekki aðeins atvinnulífið sem gerir kröfur til foreldra, skóli barnanna gerir pað einnig. Sunna benti á að samkvæmt lögum bera „foreldrar ... ábyrgð á skólagöngu barna sinna“ og umsjónarkennararnir voru meðvitaðir um pessar skyldur foreldra. Kennararnir sögðust gera pá kröfu til foreldra að peir styddu við heimanám barna sinna, pá sérstaklega „heimalestur“ (Puríður). Peir vildu að foreldrar „hjálp[uðu] börnunum sínum að koma með pað sem á að koma með í skólann ... [svo sem] sunddóti[ð], ... lestrarkvittunarbók[ina] eða nesti[ð]“ (Guðrún). Deir vildu að „foreldrar myndu ... lesa alla [tölvu]pósta frá“ peim (Ólína) og myndu taka „á pví sem ... [skólinn] er að biðja um“ (Snæfríður). Einnig myndu peir vilja að foreldrar gæfu „sér tíma til að koma, allavegana á pessa foreldrafundi $[\mathrm{og}]$... kynningar" í skólanum (Puríður). Samkvæmt lögum bera foreldrar „ábyrgð á námi barna sinna“ (lög um grunnskóla nr. 91/2008, 19. gr.) og umsjónarkennararnir gera pá kröfu að peir sinni pessari skyldu sinni. Velta má fyrir sér hvort sumir foreldrar átti sig ekki á pessari „ábyrgð“ sinni eða leggi annan skilning í hana en umsjónarkennararnir. Einnig gæti verið að prátt fyrir að sumir kennaranna hafi tekið fram að „allir [foreldrar væru að] gera eins vel og peir get““ (Sunna) vanti að tekið sé nægjanlegt tillit til ólíkra aðstæðna foreldra, til dæmis peirra sem lifa við „verulega erfiðar félagslegar aðstæður" (Guðrún). Pá gæti einnig verið að foreldrar hafi einfaldlega ekki tíma eða orku til að sinna pessum kröfum skólans.

Ýmislegt fleira kemur til sem getur valdið álagi á foreldra en „mjög margir [peirra] eru ofboðslega uppteknir" að mati umsjónarkennaranna. Sumir „eru í premur vinnum, eru í mastersnámi og eiga prjú börn undir sjö ára,“ sagði Guðrún. Aðrir töluðu um kröfuna um að foreldrar „stund[i] [auk pess] líkamsrækt“ (Kolbrún) og að pað væri tímafrekt. Enn aðrir töluðu um að fólk væri „upptekið af pví að fara til útlanda“ (Magnús) og Kolbrún talaði um kröfuna um að „fara í 13 jólahlaðborð“ í aðdraganda jólanna. Hún sagði: „Ekki segja mér að pað sé nauðsynlegt“ en bætti svo við: „En einhvern veginn upplifir fólk petta pannig í dag." Puríður tók undir og sagði: „Kröfurnar á foreldra eru gríðarlegar. Pú ert ekki maður með mönnum nema pú ... gerir petta ... og eigir petta." Sömuleiðis töluðu margir umsjónarkennaranna um að ípróttir og tómstundir barna ættu pátt í streitu og álagi á foreldra. Að mati umsjónarkennaranna fylgir pví álag fyrir foreldra að keyra og sækja börnin í ípróttir og tómstundir, vera inni í öllu skipulagi og mæta á mót, sýningar og viðburði auk pess „að vera í foreldraráði, baka fyrir [köku]basarinn og vera í fjáröfluninni“ (Snæfriðður). Petta er í takt við aðrar rannsóknarniðurstöður um mörg verkefni foreldra og upplifun peirra af streitu (Andrea Hjálmsdóttir og Marta Einarsdóttir, 2019). Pessar lýsingar kennaranna á lífsstíl foreldranna eru áhugaverðar, sérstaklega í ljósi pess að kennararnir störfuðu á ólíkum stöðum á landinu, í dreifbýli, sjávarporpi og höfuðborginni, par sem meðaltekjur íbúa eru mismunandi. Velta má fyrir sér hvort foreldrar upplifi kröfu um pennan lífsstíl óháð búsetu og félagslegum bakgrunni.

Pað er ekki aðeins álag á foreldra heldur fara börnin ekki varhluta af pví. Sem dæmi pá töluðu umsjónarkennararnir um að of mikil áhersla væri á keppni í ípróttum barna með tilheyrandi álagi á 
börnin. „Við sem pjóðfélag purfum að fara að skoða [tilgang íprótta og] æfinga sem börnin eru á ... pau eru ekkert öll að fara að vera eitthvað keppnisfólk í ípróttum“ (Ólína). Peir töldu að pað vantaði æfingar fyrir „pau börn sem vilji bara æfa tvisvar sinnum í viku til pess að fá hreyfingu og gera eitthvað skemmtilegt“. Auk pess bentu nokkrir peirra á að sum börn stundi margar ípróttir og/eða tómstundir. Sum eru í „of miklu ... eins og barnið sem er í dansi, handbolta og fiðlunámi“ og fer „til útlanda á dansmót tvisvar til prisvar sinnum á vetri,“ sagði Guðrún. Pessu getur fylgt mikið álag og streita að mati umsjónarkennaranna. Рað rímar við niðurstöður Skúla Helgasonar og félaga (2017). Pá höfðu umsjónarkennararnir áhyggjur af að of mikil pátttaka í ípróttum og tómstundum hefði áhrif á pann tíma sem börn hefðu fyrir frjálsan leik eftir skóla, en „frjáls leikur er dásamleg leið til pess að slaka á,“ sagði Kolbrún og bætti við að hann væri „kannski svolítið vanmeti[nn] hjá mörgum“. Pekkt er að ípróttir og tómstundir hafi jákvæð áhrif á börn (Vandell o.fl., 2019) en samkeppni getur haft neikvæð áhrif (Hrefna Pálsdóttir o.fl., 2011). Velta má fyrir sér hvort pað sé ekki óparfa álag á börn að hafa pessa áherslu á keppni en stór hluti peirra barna sem stunda ípróttir æfa eða keppa allt að fimm sinnum í viku (Margrét Lilja Guðmundsdóttir o.fl., 2020). Erum við ekki einnig að ætla börnunum um of að taka pátt í mörgum tómstundum á sama tíma?

Við álagið bætist sú krafa að nú purfa allir að eiga allt að mati umsjónarkennaranna. Sem dæmi töldu peir að stærstur hluti nemenda ætti sinn eigin snjallsíma: „Í pessum bekk mínum [börn í 6. bekk] pá veit ég ekki um neitt barn sem er ekki með [sinn eigin] snjallsíma“" (Magnús). Umsjónarkennararnir upplifa einnig að allir purfi að hafa aðgang að öllu. Peir sögðu að margir nemenda peirra hefðu fengið leyfi hjá foreldrum sínum fyrir aðgangi að samfélagsmiðlum líkt og Snapchat, Facebook og Instagram prátt fyrir að stór hluti barnanna hafi ekki aldur til að nota pessi smáforrit. Sumir umsjónarkennaranna lýstu áhyggjum sínum af áhrifum alls pessa á börn. Pað er "ekkert að ástæðulausu“ (Ólína) að „kvíði og depurð ... virðist vera að einkenna alltof mikið af nemendum okkar núna“ (Margrét). Pað er afleiðing allra pessara krafna og hraða sem einkennir íslenskt samfélag, sögðu peir. Hvað sem veldur pá er vissulega vert að taka pað alvarlega að hluti nemenda á pessum aldri finnur fyrir depurð (Einar B. Porsteinsson og Ársæll Arnarsson, 2018) og pónokkrir fyrir kvíða (Brynja Örlygsdóttir o.fl., 2016).

\section{Aukin krafa frá foreldrum um að kennarar komi meira að uppeldi barna}

Umsjónarkennararnir sögðust upplifa álag í starfi og „auk[na] press[u] frá foreldrum og kröfur um hvað skólinn ... [og kennararnir] ættu að gera“ (Kolbrún). Peir sögðust upplifa, í auknum mæli, að foreldrar vildu að peir kæmu að uppeldi nemenda og leiðbeindu peim í samskiptum við félagana, eða eins og Snæfríður sagði: „Рað aukast alltaf bara kröfurnar um að maður geri meira og meira fyrir pau [nemendurna] og sinni meira uppeldinu." Sambærilegt kom fram í rannsókn Erlu Sifjar Markúsdóttur og Lilju M. Jónsdóttur (2016).

Almennt fannst umsjónarkennurunum að börnin væru „náttúrulega“ á peirra „ábyrgð“ (Margrét) pegar pau væru hjá peim í skólanum, en peim fannst að „foreldrar verði líka að taka ábyrgð“ (Ólína). Að peirra mati ætti pað ekki að vera eingöngu skólans að fræða börnin. Foreldrar mættu ekki fría sig ábyrgð til dæmis hvað varðar heimanám barna pó upplifun peirra væri að mörgum foreldrum pætti pað „rosalega pægilegt ef kennarinn í skólanum getur séð um petta [heimanámið] og við [foreldrarnir] getum pá bara einbeitt okkur að einhverju öðru“ (Magnús). Рað sama á við um uppeldi og hin ýmsu samskiptamál sem upp koma í skólanum. Peir töluðu um pann mikla tíma sem pað tæki frá kennslunni að leysa hin ýmsu samskiptamál sem upp kæmu meðal nemenda og sumum fannst peir „bara alls ekki“ hafa tíma til pess pví verkefnin fyrir væru næg, eða eins og Ólína sagði: „Ég er bara með alls konar nemendur [sem parf að sinna] og pað eru alls konar mál [sem parf að leysa] og ... ofboðslega mikið hjá mér af fundum [sem ég parf að mæta á] og pað kemur bara niður á undirbúningi á kennslunni." Að mati umsjónarkennaranna vilja sumir foreldrar varpa allri ábyrgð á skólann pegar kemur að pví að leysa mál er varða börn peirra á skólatíma. Sumir foreldrar eru „bara fegnir“ að barnið sé í skólanum pví pá „er vandamálið ekki peirra“ (Sunna). Samkvæmt lögum bera foreldrar „höfuðábyrgð“ á börnum sínum (lög um samning Sameinuðu pjóðanna um réttindi barnsins nr. 19/2013). Deir bera „ábyrgð á námi“ peirra (lög um grunnskóla nr. 91/2008, 19. gr.) og hegðun 
(reglugerð um ábyrgð og skyldur aðila í skólasamfélaginu nr. 1040/2011). Umsjónarkennararnir telja pó suma foreldra vera að reyna að varpa aukinni ábyrgð á pá en peir vilja fæstir taka við peirri ábyrgð, eða eins og Margrét sagði:

Foreldrar eru svolítið góðir í að varpa ábyrgðinni annað ... Ég upplifi pað að foreldrar eru sífellt meira að setja hlutverk sitt yfir á okkar [kennaranna] herðar ... Ég fæ rosalega oft [frá foreldrum] spurninguna hvað ætlar pú að gera í málinu? Mig langar bara að varpa henni [spurningunni] til baka, [og fá] ... foreldra [til að axla] ... ábyrgðina.

Skiptar skoðanir voru meðal umsjónarkennaranna um að hve miklu leyti peir ættu að koma að pví sem gerðist utan skólatíma. Peir upplifðu pó talsverðar kröfur frá foreldrum um að peir gerðu pað. Sem dæmi sagðist Kolbrún stundum fá til sín „nánast bara grátandi“ foreldra „á mánudagsmorgnum eftir samskipti“ barnanna við félaga sína um helgina og peir bæðu hana um að ganga í málið. Ólína sagði frá foreldri fyrrum nemanda síns sem hafði haft samband við skólann vegna samskipta nemandans við aðra nemendur „á netinu ... utan skóla[tíma]“ og vildi að hún „gerð[i] eitthvað í pvi““. Umsjónarkennararnir voru pó sammála um að pað væri „ekki beint“ hlutverk peirra (Margrét) að taka á peim samskiptamálum sem fara fram utan skólans og að pessi mál ættu að vera „á ábyrgð foreldra" (Snæfríður). Margir peirra sögðust pó reyna að vinna pessi mál með foreldrum.

Fæstum fannst pað vera sitt „hlutverk“ að veita foreldrum ráð varðandi uppeldi nema að „mjög takmörkuðu marki“ (Guðrún), pó einhver hafi sagt að pað væri „alveg 100\% [peirra hlutverk] ... að styðja pau [foreldrana] í uppeldi“ (Kolbrún). Nokkrir töluðu pó um að „stundum purfi maður að gera meira af pvi“ að styðja foreldra en peim fyndist vera innan síns verksviðs (Guðrún). Í pví sambandi benti Margrét á að stundum væri „mjög erfitt að fá ... faglega aðstoð“, biðin eftir sérfræðingum væri „ofboðslega löng“ og pví pyrftu kennarar stundum að ganga í málið. Almennt töluðu umsjónarkennararnir um að foreldrar leituðu ekki mikið ráða hjá peim varðandi uppeldi. Рað væri pó helst pegar foreldrarnir væru komnir í „öngstræti“ (Magnús) með einhver mál svo sem „kvíða og reiðistjórnun“ (Margrét) eða „hegðunarvanda“" (Margrét) að peir leituðu til peirra. Í lögum kemur fram að skólinn eigi að „stuðla að alhliða proska“ barna í „samvinnu við heimilin“ (lög um grunnskóla nr. 91/2008, 2. gr.). Alhliða proski er afar vítt hugtak en pað er ekki útskýrt nánar í lögum hvað í pví felst né hvernig pessari samvinnu eigi að vera háttað. Рað er pví kannski ekki skrýtið að óvissa ríki meðal foreldra og umsjónarkennara um hver beri ábyrgð á málum eins og samskiptum barna við félaga sína. Kennarastéttinni ber að sinna „uppeldi“ barna (Mennta- og menningarmálaráðuneyti, 2011) og umsjónarkennarinn ber ábyrgð á proska, „líðan og velferð“ barna en í hverju pað nákvæmlega felst er ekkert fjallað um í lögum eða aðalnámskrá, né hvort pað eigi eingöngu við á skólatíma eða hvort kennarar eigi að koma að málum sem gerast utan skóla.

Umsjónarkennararnir greindu frá pví að peim fyndust pessi samskipti og stuðningur peirra við foreldra í uppeldishlutverkinu fela í sér mikið álag og „streitu“ (Magnús). „Ég var eiginlega að bugast,“ sagði Snæfrỉður, „pví ég var búin að fá svo mikið nóg af nokkrum mæðrum umsjónarnemenda minna sem voru ítrekað að hafa samband við mig vegna samskipta barnanna“. Magnús talaði um álag vegna mikils aðgengis foreldra að kennurum, sem dæmi hefðu foreldrar verið að senda peim skilaboð seint „á sunnudagskvöldum ... í gegnum Facebook“. Athugasemdir peirra endurspegla fyrri rannsóknir sem sýna að kennarar finna fyrir álagi í starfi, jafnvel svo miklu að pað leiði til kulnunar (Sif Einarsdóttir o.fl., 2019; Snæfríður Dröfn Björgvinsdóttir og Anna-Lind Pétursdóttir, 2014).

Við petta bætist að umsjónarkennurunum finnst peir ekki hafa verið búnir undir petta hlutverk í námi sínu. Peir segjast hafa fengið leiðsögn um hvernig eigi að ráðleggja foreldrum um heimanám en „sorglega lítið“ (Margrét) um „hegðun“ (Ólína) eða uppeldi. Peir hefðu viljað læra meira um samstarf við foreldra og hegðun barna. „Ég er bara ekki menntuð á pví sviði,“ sagði Margrét og bætti við að pau væru „að fá svo hrikalega flókin mál inn til okkar nú orðið - eitthvað sem við erum bara engan veginn undirbúin að takast á við“. Undanfarin ár hefur áhersla á foreldrasamstarf og tengsl heimilis og skóla verið aukin í kennaranámi (Háskóli Îslands, e.d.-a; Háskólinn á Akureyri, e.d.) en velta má fyrir sér hvort pað sé nóg eða eigi að vera meira. Sunna sagði að hún væri alltaf að sjá pað „betur og betur“ hversu mikilvæg „pverfagleg menntun [starfsfólks væri] innan skólans“ pannig að ólíkar fag- 
stéttir gætu stutt hver aðra við að leysa pau mál sem upp koma. Velta má fyrir sér hvort pað væri ekki mikilvægur stuðningur við kennara að ráða inn í skólana sérmenntað fólk sem geti stutt og leiðbeint foreldrum eins og peir hafa sjálfir bent á (Skúli Helgason o.fl., 2017).

\section{Pörf á aukinni uppeldisfræðslu og stuðningi fyrir foreldra}

Umsjónarkennurunum fannst framboð á uppeldisfræðslu, námskeiðum og ráðgjöf til foreldra ekki nægjanlegt. Sú pjónusta sem sé í boði væri „bara rosalega lítil og léleg“ (Sunna) og „langir biðlistar“ (Margrét) sem væri „skammarlegt“ að mati Magnúsar. Fræðsla ætti að vera í boði fyrir foreldra allra barna að peirra mati - ekki aðeins ef barnið er „ofvirkt, með athyglisbrest og mótpróaprjóskuröskun“ (Guðrún). Peir töluðu um að úrræðin sem nú væru í boði væru „kostnaðarsöm“ og væru pví „ekkert fyrir alla" foreldra (Ólína). Sumir peirra undruðu sig á að foreldrum byðist eingöngu fræðsla og stuðningur rétt eftir fæðingu barns en pá væri ,ágætis ... utanumhald, upplýsingar og svoleiðis yfir í bara ekki neitt" pegar barnið yrði eldra (Magnús). Peir töldu að auka pyrfti stuðning og fræðslu fyrir foreldra skólabarna. Nokkrir peirra lögðu áherslu á að pað að fara á „uppeldisnámskeið“ (Guðrún) „ætti að vera algjörlega [eðlilegur] partur af pví að eiga börn“ (Kolbrún). Sumir sögðust pó finna fyrir ákveðnum fordómum gagnvart pví að foreldrar leituðu sér aðstoðar við uppeldið eins og foreldrar sem pað gerðu fyndu „pínu til sektar eða skammar“ (Kolbrún).

Umsjónarkennararnir vildu sjá „miklu meiri og almennari“ (Kolbrún) fræðslu og stuðning í boði fyrir „hið almenna foreldri“ (Ólína). „Meira svona fyrirbyggjandi“ fræðslu, sagði Snæfríður sem lagði áherslu á að gripið væri inn í áður en komið væri „ófremdarástand“. Samkvæmt leit höfunda pessarar greinar virðist pó afar lítið vera um almenna fræðslu og stuðning fyrir foreldra 10-13 ára barna pó ýmislegt sé í boði ef upp er kominn vandi. Vonandi geta útskrifaðir MA-nemendur úr foreldrafræðslu og uppeldisráðgjöf (Háskóli Íslands, e.d.-b) uppfyllt pessa pörf í framtíðinni. Umsjónarkennararnir töldu foreldra purfa pessa almennu fræðslu um uppeldi: Leiðsögn um „hvernig maður elur upp börn“ (Guðrún) og „mismunandi uppeldisaðferðir“ (Sunna) og hvernig peim skuli beitt. Peir töldu margir að foreldrar pyrftu leiðsögn við , að setja börnum [sínum] mörk“ (Snæfríður) og gæta pess að vera ekki alltaf „eftirlát[ir]“ (Kolbrún). Peir töluðu um ,agaleysi“ sem „part af pessu [íslenska] pjóðfélagi“ (Ólína) og sögðu pað „alveg ótrúlegt hvað mörg börn eru frek og tilætlunarsöm“ (Guðrún). Ólína lýsti reynslu sinni af að flytja heim eftir að hafa búið erlendis um tíma: „Ég var bara í sjokki ... krakkarnir voru bara upp um allt og út um allt pú veist og rifu kjaft." Velta má fyrir sér hvort petta haldist í hendur við áherslu á frelsi í uppeldi á Íslandi (Jóhanna Einarsdóttir, 2006). Magnús bætti við: „Við viljum [að] sjálfsögðu ala börnin okkar pannig upp að pau finni að peim er frjálst að segja hvað sem er og hafa sínar skoðanir en pú parft að vera kurteis“ og rímar pað við heillavænlega uppeldishætti par sem áhersla er lögð á góð samskipti, að foreldrar styðji börn sín, hlusti á pau, beri virðingu fyrir skoðunum peirra og setji peim mörk (Baumrind, 1971; Steinberg, 2001; WHO, 2012).

Annað sem umsjónarkennararnir nefndu var að brýnt væri að fræða foreldra um mikilvægi samveru foreldra og barna. Peir höfðu áhyggjur af að „samvera foreldra og barna ... [væri] minni en áður“ (Puríður) og töldu pví mikilvægt að minna foreldra á mikilvægi pess að verja tíma með börnum sínum og tala saman, enda hefur mikilvægi samveru foreldra og barna komið skýrt fram í rannsóknum (Sigrún Aðalbjarnardóttir, 2019; Steinberg, 2001). Samskipti voru umsjónarkennurunum hugleikin. Peir töldu mikilvægt að foreldrum væri leiðbeint með hvernig best væri að hátta „samskipt[um] við börn sín“ (Margrét) en einnig hvernig peir gætu hjálpað börnum sínum að eiga góð samskipti við félagana - hvort sem væri „face to face“ eða á „netinu“ (Magnús). Snæfríður sagði að upp hefðu komið „hræðileg mál ... af pví að pau [börnin] eru á Snapchat og ráða engan veginn við petta og Instagram og bara hræðilegar myndir og hræðileg samskipti“. Sunna sagði pau stundum „segja svo ljótt um hvert annað parna inni“ og í ákveðnum tilvikum væri petta „einelti“. Mikilvægt er að börnum séu kennd góð samskipti strax í æsku, bæði fyrir nútíð og framtíð peirra (Sigrún Aðalbjarnardóttir, 2019; Taylor o.fl., 2017).

Umsjónarkennararnir töldu foreldra einnig purfa fræðslu og stuðning vegna tölvu- og snjalltækjanotkunar barna sinna. Peir upplifðu „andvaraleysi“ (Sunna) foreldra varðandi net- og skjánotkun 
barna peirra. Peir töldu foreldra oft ekki meðvitaða um hvað börnin væru að gera í tölvunni og við hverja pau ættu í samskiptum. Puríður sagði foreldra stundum „gapandi hissa [eftir stutt fræðsluerindi í skólanum] hvað sko í rauninni pað er sem börnin geta komist í tæri við og hverjir geta farið inn á heimili peirra í gegnum tölvuna" og pannig verið í samskiptum við börnin. Pá töldu margir umsjónarkennaranna foreldra ekki meðvitaða um hve miklum tíma börnin eyða fyrir framan tölvur og snjalltæki. Flestum umsjónarkennurunum fannst tölvu- og snjalltækjanotkun barna "of mikil“ (Magnús) en öðrum alveg „óhugnanleg[a]“ mikil (Puríður). Peir sögðu að sum börn, jafnvel niður í 6. bekk, væru háð símunum sínum. Umsjónarkennararnir töldu foreldra oft ekki góðar fyrirmyndir er kæmi að tölvu- og snjalltækjanotkun. „Við erum bara öll alveg rosalega lost [týnd] í sambandi við síma og tölvunotkun“ (Sunna). Við „purfum ... kannski líka sjálf sem fullorðið fólk [að líta í eigin barm] ... varðandi net- og símanotkun“ okkar sjálfra (Magnús) og vera góðar fyrirmyndir. Puríður sagðist sem dæmi heyra nemendur sína segja: „Mamma er bara alltaf í símanum [í bílnum]. ... Hún sko biður mig að fylgjast með [umferðar]ljósunum á meðan hún er í símanum.“ Snjalltækjanotkun hefur mikil áhrif á fjölskyldur í nútímasamfélagi, bæði neikvæð og jákvæð (Barr, 2019) en of mikil skjánotkun hefur neikvæð áhrif á andlega heilsu barna (Twenge og Campbell, 2018) og purfa foreldrar að vera meðvitaðir um pað.

Umsjónarkennararnir veltu fyrir sér hvernig útfæra mætti fræðslu fyrir foreldra. Sumir töluðu um að pað ætti að vera skylda fyrir alla foreldra að fara á námskeið. Til dæmis að pað væri „skylda fyrir alla [foreldra] sem eru með börn í [tilteknum] ... árgangi“ að fara á námskeið eða hlusta á „fyrirlesara“ (Guðrún), eða að pað væri til námskeið sem kennari gæti beðið um fyrir foreldra tiltekins bekkjar (Ólína). Á pessum námskeiðum væri gagnlegt að peirra mati að aðlaga fræðsluna að pörfum hvers árgangs, fjalla um proskaskeið barnanna svo foreldrar hafi einhver viðmið, viti við hverju má búast og áskoranir daglegs lífs. Раð samræmist að mörgu leyti skilgreiningu NPEN (2021) á foreldrafræðslu sem felur í sér að efla pekkingu foreldra á proska barna og sambandi foreldris og barns auk pess að stuðla að vexti í foreldrahlutverkinu. Ólína benti á að „með pví að hafa petta innan skólans sé hægt að ná til allra foreldra“. Einhverjir töluðu pó um að peir óttuðust að erfitt yrði að fá suma foreldra á slík námskeið. Ljóst er pó að umsjónarkennararnir telja foreldra purfa á stuðningi og fræðslu að halda. Рað rímar við pað sem komið hefur fram í öðrum rannsóknum að foreldrar vilja fá stuðning í uppeldishlutverkinu (Birna María Svanbjörnsdóttir, 2007; Hrund Pórarinsdóttir og Sigrún Aðalbjarnardóttir, 2010). Einhver sveitarfélög eins og Reykjavík eru að próa skólapjónustu sína með pví að bæta stuðning og ráðgjöf við foreldra (Helgi Hjartarson, e.d.) og er pað vel. Við teljum að sérmenntað fólk sem gæti frætt og stutt foreldra í uppeldishlutverkinu ætti að vera ávinningur fyrir skóla og létt á kennurum sem og verið dýrmætur stuðningur við foreldra og par með börn. Pað er í samræmi við niðurstöður um að kennarar telja aukið aðgengi að öðrum sérfræðingum geta dregið úr álagi á peirra störf (Skúli Helgason o.fl., 2017).

\section{Samantekt og lokaorð}

Eins og titill greinarinnar vísar til pá fannst umsjónarkennurunum allir vera mjög uppteknir - pað uppteknir að „enginn“ hefði tíma til að sinna börnunum. Fyrsta pemað í niðurstöðunum gerir grein fyrir peim miklu samfélagslegu kröfum sem gerðar eru til foreldra og barna. Kröfunum fylgir hraði, álag og tímaskortur. Foreldrar hafa margt á sinni könnu og pví er kannski ekki skrýtið að sumir peirra gefi sér ekki tíma eða hafi ekki orku til að „fylgjast með og styðja við skólagöngu og námsframvindu“ barna sinna eins og lög um grunnskóla (nr. 91/2008, 18. gr.) kveða pó á um. Ábyrgð foreldra á námi og hegðun barna sinna er skýr í lögum (lög um grunnskóla nr. 91/2008; reglugerð um ábyrgð og skyldur aðila í skólasamfélaginu nr. 1040/2011). Umsjónarkennararnir voru meðvitaðir um pessar skyldur og ábyrgð foreldra og vildu að peir tækju virkan pátt í námi barna sinna. Annað pemað gerir grein fyrir pví mikla álagi sem umsjónarkennararnir finna fyrir í starfi, meðal annars vegna aukinnar kröfu frá foreldrum um að peir komi meira að uppeldi barna - jafnvel utan skólatíma barnanna. Umsjónarkennararnir telja sig ekki hafa tök á að uppfylla pær kröfur foreldra. Deir telja álag í starfi sé pá pegar of mikið og verkefnin mörg. Auk pess telja peir petta varla sitt hlutverk né að peir hafi menntun til að sinna pví. Samkvæmt aðalnámskrá grunnskóla (Mennta- og menningarmálaráðuneyti, 2011) 
ber kennurum meðal annars að sinna „uppeldi“ og bera ábyrgð á „líðan og velferð“ nemenda sinna. Velta má fyrir sér hvort of mikið sé sett á herðar kennara og hvort hægt væri að draga úr álagi á pá með pví að auka aðgengi að öðrum sérfræðingum líkt og peir hafa sjálfir bent á (Skúli Helgason o.fl., 2017). Ekki eru skýrar línur um hvað sé hlutverk foreldra og hvað kennara er kemur að uppeldi barna enda er kannski flókið að telja pað upp, en vandamálið kemur skýrt fram er börn vantar stuðning og leiðsögn við að leysa úr samskiptavandamálum við félaga sína. Er pað hlutverk umsjónarkennara eða foreldra? Skiptir máli hvort málið kemur upp innan eða utan skóla? Priðja og síðasta pemað snýr að pörf foreldra á uppeldisfræðslu og stuðningi, en umsjónarkennararnir telja að auka purfi framboð á almennri fræðslu og stuðningi við foreldra 10-13 ára barna. Аð peirra mati parf að efla fræðslu fyrir foreldra um aga, mikilvægi samveru foreldra og barna og góðra samskipta. Börnin hafa mikla pörf fyrir leiðsögn í samskiptum við félaga sína og hvernig umgangast eigi snjalltæki og samfélagsmiðla. Umsjónarkennararnir töldu að gagnlegt væri að hafa fræðslu fyrir foreldra í tengslum við skólann en sumir efuðust um að foreldrar gæfu sér tíma fyrir slíkt.

Í niðurstöðum pessarar rannsóknar birtist uppeldi barna eins og heit kartafla sem foreldrar og umsjónarkennarar kasta á milli sín. Álagið á foreldra er mikið og umsjónarkennararnir upplifa að peir séu að reyna að koma ýmsum páttum uppeldis barna sinna í auknum mæli yfir á skólana, en umsjónarkennararnir nefna ýmsar ástæður fyrir pví að peir geti ekki tekið aukinn pátt í uppeldinu og vísa aftur á foreldrana. Peir telja að pær samfélagslegu kröfur sem gerðar eru til foreldra bitni á börnunum. Velta má fyrir sér hvort við sem samfélag metum uppeldishlutverkið sem skyldi. Foreldrum parf að vera kleift að sinna uppeldi barna sinna en til pess purfa peir stuðning og fræðslu að mati umsjónarkennaranna. Með hvaða hætti viljum við að skólinn styðji við uppeldi barna og hvernig getum við gert honum pað kleift? Varla er raunhæft að leggja meira á umsjónarkennara. Pví má ætla að pörf sé á sérmenntuðu fagfólki sem starfar í samvinnu við skólana og getur veitt foreldrum fræðslu og stuðning í uppeldishlutverkinu. Niðurstöður rannsóknarinnar gefa okkur mikilvæga innsýn í reynslu umsjónarkennara og mat peirra á pörf fyrir uppeldisfræðslu og stuðning við foreldra. Pörf er á frekari rannsóknum par sem sýn foreldranna sjálfra er skoðuð.

\section{Pakkir}

Anna Lilja Einarsdóttir fær okkar bestu pakkir fyrir dýrmæta aðstoð við texta- og heimildavinnu. Umsjónarkennararnir, sem tóku pátt í rannsókninni, fá sérstakar pakkir fyrir pátttökuna og fyrir að deila reynslu sinni.

\section{"Now, everyone is so busy that there is no one to take care of the children": Need for parent education: Perspectives of supervisory teachers in middle school.}

Family life has changed in recent decades and become more complex, leading to new challenges regarding children's upbringing. In modern society, most parents have jobs outside of the home and children spend a large part of their day in school. Therefore, we can assume that supervisory teachers are aware of children's needs, as well as their parents, due to the emphasis on cooperation between school and home (lög um grunnskóla [Act on Compulsory Education] no. 91/2008; Mennta- og menningarmálaráðuneyti, [Ministry of Education and Culture], 2011).

The aim of the study is to provide insight into the challenges associated with parenting children 10-13 years of age in modern society, according to Icelandic supervisory teachers' estimation. Moreover, the objective is to explore the teachers' perspectives on parents' and supervisory teachers' roles and responsibilities in parenting, along with their estimation of the need for parental support and parent education. The data consists of semi-struct- 
ured interviews with eight supervisory teachers in 5th-7th grade in middle schools. The data was analysed using thematic analysis (Braun og Clarke, 2006). Three main themes were explored: (1) High sociological demands are made on parents and children; (2) increasing demands from parents on teachers to participate more in children's upbringing and; (3) the need for increased parental support and parent education.

The main findings revealed that Icelandic society places significant pressure and demands on parents, resulting in parents' busy lives. These sociological demands cause Icelandic society to be fast-paced, with parents lacking time, thus causing stress and strain on families. The job market plays a major role in this high tempo. The schools also make demands on parents, such as monitoring the children's academic progress. Children's after school activities makes demands on parents as well. Additionally, parents' social and personal lives are a source of strong pressure. Therefore, it is not surprising that some parents have neither the time nor energy to monitor and support their children's school attendance and academic progress, as the elementary school law stipulates (nr. 91/2008, paragr. 18). Parents' responsibilities for their children's education and behavior are clearly expressed in the law of the land (lög um grunnskóla no. 91/2008; Reglugerð um ábyrgð og skyldur aðila í skólasamfélaginu [Regulation on the Responsibilities and Obligations of Partners in the School Community] no. 1040/2011) and teachers require parents to be more actively involved in their children's education.

Teachers experience increasing demands from parents to the effect that teachers participate more in children's upbringing. For instance, many parents want teachers' assistance in solving communication difficulties between children, even in cases that happen after school hours. However, the teachers do not feel able to meet these demands. They say the workload and related stress is already excessive. Besides, they do not see this as part of their job as teachers nor are they trained in field of parent education. The teachers would have liked to learn more about collaboration between school and parents during their education process. According to the National Curriculum Guide (Mennta- og menningarmálaráðuneyti, 2011), teachers are obliged to attend to the upbringing of their students and are responsible for their well-being However, it is not further explained what this entails. The role of parents and teachers, respectively, remains unclear. A good example of this vagueness is when children need support and guidance in solving communication problems with their peers. Is that the role of teachers or parents? Does it matter whether this happens during or after school hours?

The teachers want parents to take responsibility for their children. They think there is a real need for parent education and parental support in bringing up 10-13 year old children. The teachers say that parents need to be educated in setting limits and boundaries and emphasize the importance of parents spending time and communicating successfully with their children. The children urgently need guidance in using computers and smart devices, especially when it comes to social media. Some of them have access to their own social media accounts, despite the age limit being 13 years or older. Some of the teachers expressed concerns regarding the effect these factors have on children and speculated that this could have a negative influence with respect to anxiety and depression among children. The teachers said it would be beneficial to conduct parent education in the schools although some doubted that parents would take the time to attend.

The results of this study should be an important contribution to the discussion on parents' and teachers' roles and responsibilities in children's upbringing. Also, the findings are important for policy formulation regarding parent education and support for those who work with parents. Thus, the findings should be of value both for parents and their children.

Keywords: Parents, children, upbringing, middle school, teachers, parent education 


\section{Um höfunda}

Sigrún Helgadóttir (sigrhelg@gmail.com) lauk BA-prófi í uppeldis- og menntunarfræði (2006) frá Háskóla Íslands, námi í kennslu réttindum í grunn- og framhaldsskóla (2008) frá Kennaraháskóla Íslands og MA-prófi í foreldrafræðslu og uppeldisráðgjöf (2019) frá Háskóla Íslands. Sigrún hefur starfað sem umsjónarkennari á miðstigi og sem deildarstjóri/staðgengill skólastjóra en starfar nú sem verkefnastjóri við grunnskólann Flóaskóla.

Hrund Pórarins Ingudóttir (hrundin@hi.is) er lektor í uppeldis- og menntunarfræði á Menntavísindasviði Háskóla Íslands. Hrund lauk meistaraprófi (2008) og doktorsprófi (2015) í uppeldis- og menntunarfræði frá Háskóla Íslands. Hrund stundaði nám í foreldrafræðslu og uppeldisráðgjöf við University of Minnesota sem hluta af doktorsnámi sínu. Helstu rannsóknarsvið Hrundar eru uppeldissýn foreldra - gildi peirra, markmið og leiðir en einnig próun foreldrafræðslu og uppeldisráðgjafar á Íslandi.

\section{About the authors}

Sigrun Helgadottir (sigrhelg@gmail.com) completed a bachelor’s degree in education studies (2006) from the University of Iceland, a degree in teaching at elementary and high school levels (2008) from Iceland College of Education and a master's degree in parent education (2019) from the University of Iceland. Sigrun has worked as a teacher in middle school and as an assistant principal. She currently works as a project manager at Floaskoli.

Hrund Thorarins Ingudottir (hrundin@hi.is) is an assistant professor in education studies at the School of Education, University of Iceland. Hrund completed her master's degree (2008) and a Ph.D. (2015) in education studies from the University of Iceland. She studied parent education at the University of Minnesota as a part of her doctoral thesis. Her research focuses on parents' pedagogical vision and the development of parent education in Iceland.

\section{Heimildir}

Alonso, R. F., Díaz, M. Á., Woitschach, P., Álvarez, J. S. og Cuesta, M. (2017). Parental involvement and academic performance: Less control and more communication. Psicothema, 29(4), 453-461. https://doi. org/10.7334/psicothema2017.181

Andrea Hjálmsdóttir og Marta Einarsdóttir. (2019). „Mér finnst ég stundum eins og hamstur í hjóli“: Streita í daglegu lífi fölskyldufólks á Íslandi. Íslenska pjóðfélagið, 10(1), 4-19. https://www.rha.is/static/files/hamstur-i-hjoli_grein_marta-og-andrea.pdf

ART-teymið á Suðurlandi. (e.d.). Fjölskyldu-ART. https://www.isart.is/fjolskyldu-art/

Ársæll Arnarsson. (2019). Depurð meðal skólabarna á Íslandi. Sérrit Netlu 2019-Alpjóðlegar menntakannanir. https://doi.org/10.24270/serritnetla.2019.30

Ársæll Már Arnarsson, Sigrún Daníelsdóttir og Rafn Magnús Jónsson. (2020). Félagstengsl islenskra barna og ungmenna. https://www.landlaeknir.is/servlet/file/store93/item41614/Félagstengslbarnaogungmenna_LOK.pdf

Baldur Kristjánsson. (2001). Barndomen och den sociala moderniseringen: Om att växa upp i Norden på tröskeln till et nytt millennium [doktorsritgerð]. Lärarhögskolan í Stokkhólmi, Svípjóð.

Barnalög nr. 76/2003.

Barnaverndarlög nr. 80/2002.

Barr, R. (2019). Parenting in the digital age. Í M. H. Bornstein (ritstjóri ritraðar), Handbook of parenting: 5. bindi: The practice of parenting (3. útgáfa, bls. 380-409). Routledge.

Baumrind, D. (1971). Current patterns of parental authority. Developmental Psychology Monographs, 4(1), 1-103. 
Birna María Svanbjörnsdóttir. (2007). Vilja foreldrar stuðning í foreldrahlutverkinu? Uppeldi og menntun, 16(2), 95-115. https://timarit.is/page/5209223\#page/n94/mode/2up

Braun, V. og Clarke, V. (2006). Using thematic analysis in psychology. Qualitative Research in Psychology, 3(2), 77-101. https://doi.org/10.1191/1478088706qp063oa

Braun, V. og Clarke, V. (2013). Successful qualitative research: A practical guide for beginners. Sage.

Brynja Örlygsdóttir, Ragnheiður Ósk Erlendsdóttir, Sigriðður Birta Kjartansdóttir og Ólöf Gunnhildur Ólafsdóttir. (2016). Mat á mælitækinu SCARED til að skima fyrir kvíða: Notkun í heilsuvernd skólabarna. Í Guðrún Kristjánsdóttir, Sigrún Aðalbjarnardóttir og Sóley S. Bender (ritstjórar), Ungtfólk: Tekist á við tilveruna (bls. 111-128). Hið íslenska bókmenntafélag.

Clarke, V., Braun, V. og Hayfield, N. (2015). Thematic analysis. Í J. A. Smith (ritstjóri), Qualitative psychology: A practical guide to research methods (bls. 222-248). Sage.

Collins, W. A. og Madsen S. M. (2019). Parenting during middle childhood. Í M. H. Bornstein (ritstjóri ritraðar), Handbook of parenting: 1. bindi: Children and parenting (3. útgáfa, bls. 81-109). Routledge.

Crnic, K. A. og Coburn, S. S. (2019). Stress and parenting. Í M. H. Bornstein (ritstjóri ritraðar), Handbook of parenting: 4. bindi: Social conditions and applied parenting (3. útgáfa, bls. 421-448). Routledge.

Einar B. Porsteinsson og Ársæll Arnarsson. (2018). Heilsa og liffkjör skólanema á Íslandi. https://www.stjornarradid.is/library/01--Frettatengt---myndir-og-skrar/MRN/HBSC_Skýrsla\%202018_Landssvæði.pdf

Erla Sif Markúsdóttir og Lilja M. Jónsdóttir. (2016). „Đegar maður finnur að krökkunum líður vel og eru kátir í skólanum, pá er takmarkinu nád“: Um hlutverk, ábyrgð og skyldur umsjónarkennara. Netla - Veftímarit um uppeldi og menntun. http://netla.hi.is/greinar/2016/ryn/04_ryn_arsrit_2016.pdf

Foreldrahús. (e.d.). Foreldrahús. https://www.foreldrahus.is/

Hagstofa Íslands. (e.d.-a). Innflytjendur eftir kyni og sveitarfélagi 1. janúar 1996-2021. https://px.hagstofa.is/ pxis/pxweb/is/Ibuar/Ibuar_mannfjoldi_3_bakgrunnur__Uppruni/MAN43005.px

Hagstofa Íslands. (e.d.-b). Tekjur eftir sveitarfélögum og kyni 1990-2020 - Sveitarfélagaskipan 1. janúar 2020. https://px.hagstofa.is/pxis/pxweb/is/Samfelag/Samfelag_launogtekjur_3_tekjur_1_tekjur_skattframtol/ TEK01002.px

Háskólinn á Akureyri. (e.d.). Kennarafræði, B.Ed. 180 einingar. https://ugla.unak.is/kennsluskra/index. php?tab=nam\&chapter $=$ namsleid\&id $=640014 \_20216 \&$ kennsluar $=2021 \& l i n a=402$

Háskóli Íslands (e.d.-a). Deild kennslu- og menntunarfræði. https://ugla.hi.is/kennsluskra/index.php?tab=skoli\&chapter $=$ content $\&$ id $=45979$

Háskóli Îslands. (e.d.-b). Foreldrafræðsla og uppeldisráðgjöf, MA, 120e. https://ugla.hi.is/kennsluskra/index. php?tab=skoli\&chapter $=$ content $\&$ id $=46086 \&$ kennsluar $=2021$

Háskóli Íslands. (2019). Siðareglur. https://www.hi.is/haskolinn/sidareglur

Hegðunarráđgjöf. (2017). Pjónusta. https://www.hegdun.is/copy-of-um-hegdunarradgjoef

Heilsugæsla höfuðborgarsvæðisins. (e.d.). Meðferð við kvíða hjá 6-12 ára börnum. https://www.heilsugaeslan. is/um-hh/frettasafn/stok-frett/2021/11/25/Medferd-vid-kvida-hja-6-12-ara-bornum/?fbclid=IwAR2SGhW7M3Dv3_RkmcelfgfVFowAAcerjdikyXKzzxLYUi-sCMZybs1roS0

Heimili og skóli. (e.d.). Fræðsla. https://www.heimiliogskoli.is/fraedsla

Helgi Hjartarsson. (e.d.). Kynning á starfi og áherslum skólapjónustu Reykjavíkurborgar: Reykjavíkurmódelið. https://www.greining.is/static/files/2019/Vorradsstefna_2019/helgi_hjartarson.pdf

Hrefna Pálsdóttir, Inga Dóra Sigfúsdóttir, Jón Sigfússon og Álfgeir Logi Kristánsson. (2011). Ungt fólk 2011: Menntun, menning, ipróttir, tómstundir, hagir og liðan nemenda i 5., 6. og 7. bekk. http://hdl.handle.net/10802/4483

Hrund Pórarinsdóttir og Sigrún Aðalbjarnardóttir. (2010). Sýn foreldra á uppeldishlutverk sitt. Í Salvör Nordal, Sigrún Júlíusdóttir og Vilhjálmur Árnason (ritstjórar), Ritröð Siðfreððistofnunar: Siðfrađi og samtimi: Velferð barna, gildismat og ábyrgð samfélags (bls. 115-133). Siðfræðistofnun og Háskólaútgáfan.

Ingvar Sigurgeirsson og Ingibjörg Kaldalóns. (2006). Gullkista við enda regnbogans. Rannsókn á hegðunarvanda i grunnskólum Reykjavikur skólaárið 2005-2006. https://notendur.hi.is/ingvars/agi/Skyrsla_Hegdun_Lokagerd.pdf 
Jóhanna Einarsdóttir. (2006). Between two continents, between two traditions. Í Jóhanna Einarsdóttir og J. T. Wagner (ritstjórar), Nordic childhoods and early education: Philosophy, research, policy, and practice in Denmark, Finland, Iceland, Norway, and Sweden (bls. 159-182). IAP Information Age.

Jóna Karen Sverrisdóttir, Ólafur Elínarson og Sarah Knappe. (2013). SAFT könnun á netnotkun barna og unglinga. http://saft.is/wp-content/uploads/2017/09/Barnakönnun_4022745_SAFT_170314.pdf

Kolbeinn H. Stefánsson. (2008). Samspil vinnu og heimilis: Álag og árekstrar. http://thjodmalastofnun.hi.is/ sites/thjodmalastofnun.hi.is/files/skrar/working_paper_of_chapter_4.pdf

Lemola, S., Perkinson-Gloor, N., Brand, S., Dewald-Kaufmann, J. F. og Grob, A. (2015). Adolescents' electronic media use at night, sleep disturbance, and depressive symptoms in the smartphone age. Journal of Youth and Adolescence, 44, 405-418. https://doi.org/10.1007/s10964-014-0176-x

Litla kvíðameðferðarstöðin. (e.d.). Opin námskeið. https://www.litlakms.is/opin-namskeid

Livingstone, S., Haddon, L., Görzig, A. og Kjartan Ólafsson. (2011). Risks and safety on the internet: The perspective of European children. Full findings and policy implications from EU kids online survey of 9-16 year olds and their parents in 25 countries. http://eprints.lse.ac.uk/id/eprint/33731

Livingstone, S., Mascheroni, G., Dreier, M., Chaudron, S. og Lagae, K. (2015). How parents of young children manage digital devices at home: The role of income, education and parental style. http://eprints.lse.ac.uk/id/ eprint/63378

Lög um grunnskóla nr. 91/2008.

Lög um persónuvernd og vinnslu persónuupplýsinga nr. 90/2018.

Lög um samning Sameinuðu pjóðanna um réttindi barnsins nr. 19/2013.

Margrét Lilja Guðmundsdóttir, Jón Sigfússon, Erla María Tölgyes, Inga Dóra Sigfúsdóttir, Ingibjörg Eva Pórisdóttir og Álfgeir Logi Kristjánsson. (2020). Ungt fólk 2019 5., 6. og 7. bekkur. Nið̋rstöður rannsóknar meðal grunnskólanema i 5., 6. og 7. bekk á Íslandi 2019. https://rannsoknir.is/wp-content/uploads/2020/10/ Ungt-folk-5.-7.bekkur-2019.pdf

Margrét Sigmarsdóttir, Örnólfur Thorlacius, Edda Vikar Guðmundsdóttir og David S. Degarmo. (2015). Treatment effectiveness of PMTO for children's behavior problems in Iceland: Child outcomes in a nationwide randomized controlled trial. Family Process, 54(3), 498-517. https://doi.org/10.1111/famp.12109

Mennta- og menningarmálaráðuneyti. (2011). Aðalnámskrá grunnskóla 2011: Almennur hluti.

Nanna Kristín Christiansen. (2011). Skóli og skólaforeldrar: Ný sýn á samstarfið um nemandann. Iðnú.

NPEN [National Parenting Education Network]. (2021). About NPEN. https://npen.org/about-npen

OECD. (e.d.). Employment rate (indicator). https://doi.org/10.1787/a452d2eb-en

OECD. (2019). Educating 21st century children: Emotional well-being in the digital age. https://doi. org/10.1787/20769679

OECD. (2020). Why parenting matters for children in the 21st century: An evidence-based framework for understanding parenting and its impact on child development. https://www.oecd.org/officialdocuments/publicdisplaydocumentpdf/?cote=EDU/WKP(2020)10\&docLanguage=En

Ólína Freysteinsdóttir, Halldór S. Guðmundsson og Kjartan Ólafsson. (2015). „Bara fimm mínútur í viðbót“: Unglingar, netnotkun og samskipti við foreldra. Uppeldi og menntun, 24(1), 53-72. https://timarit.is/ page/6330905\#page/n2/mode/2up

Páll Biering og Guðberg K. Jónsson. (2016). Einelti á veraldarvefnum: Umfang og áhrif á sálfélagslega líðan barna og unglinga. Î Guðrún Kristjánsdóttir, Sigrún Aðalbjarnardóttir og Sóley S. Bender (ritstjórar), Ungt fólk: Tekist á við tilveruna (bls. 129-148). Hið íslenska bókmenntafélag.

Ragnar F. Ólafsson. (2019). TALIS 2018: Starfshattir og viðhorf kennara og skólastjóra á unglingastigi grunnskóla. Menntamálastofnun.

Reglugerð um ábyrgð og skyldur aðila í skólasamfélaginu nr. 1040/2011.

Roskam, I., Raes, M. E. og Mikolajczak, M. (2017). Exhausted parents: Development and preliminary validation of the parental burnout inventory. Frontiers in Psychology, 8, Article 163, 1-12. https://doi.org/10.3389/ fpsyg.2017.00163

Sálstofan. (e.d.). Stilltu skapið. https://salstofan.is/skapstilling/ 
Sif Einarsdóttir, Regína Bergdís Erlingsdóttir, Amalía Björnsdóttir og Ásta Snorradóttir. (2019). Kulnun kennara og starfsaðstæður: Próun og samanburður við aðra opinbera sérfræðinga. Netla - Veftimarit um uppeldi og menntun. https://doi.org/10.24270/netla.2019.12

Sigrún Aðalbjarnardóttir. (2019). Lifssögur ungs fólks: Samskipti, áhattuhegðun, styrkleikar. Háskólaútgáfan.

Sigrún Erla Ólafsdóttir og Sigrún Aðalbjarnardóttir. (2013). „Til pess að aðrir virði mann verður maður að virða sig sjálfur": Sýn grunnskólakennara á virðingu í starfi. Netla - Veftímarit um uppeldi og menntun. https:// netla.hi.is/greinar/2013/ryn/005.pdf

Skúli Helgason, Rósa Ingvarsdóttir, Ólafur Loftsson, Hildur Ingólfsdóttir, Jónína Vala Kristinsdóttir, Eygló Friðriksdóttir, Birgitta Bára Hassenstein, Guðlaug Sturlaugsdóttir, Marta Guðjónsdóttir og Svandís Ingimundardóttir. (2017). Nýlidun og batt starfsumbverf grunnskólakennara. https://reykjavik.is/sites/default/ files/ymis_skjol/skjol_utgefid_efni/skrsla.pdf.pdf

Snæfríður Dröfn Björgvinsdóttir og Anna-Lind Pétursdóttir. (2014). Erfið hegðun nemenda: Áhrif á líðan kennara. Uppeldi og menntun, 23(2), 65-86. https://ojs.hi.is/uppmennt/article/view/1934

Soffía M. Hrafnkelsdóttir, Brychta, R. J., Vaka Rögnvaldsdóttir, Sunna Gestsdóttir, Chen, K. Y., Erlingur Jóhannsson, Sigríður L. Guðmundsdóttir og Sigurbjörn A. Arngrímsson. (2018). Less screen time and more frequent vigorous physical activity is associated with lower risk of reporting negative mental health symptoms among Icelandic adolescents. PLOS ONE, 13(4). https://doi.org/10.1371/journal.pone.0196286

Steinberg, L. (2001). We know some things: Parent-adolescent relationships in retrospect and prospect. Journal of Research on Adolescence, 11(1), 1-19. https://doi.org/10.1111/1532-7795.00001

Taylor, R. D., Oberle, E., Durlak, J. A. og Weissberg, R. P. (2017). Promoting positive youth development through school-based social and emotional learning interventions: A meta-analysis of follow-up effects. Child Development. 88(4), 1156-1171. https://doi.org/10.1111/cdev.12864

Twenge, J. M. og Campbell, W. K. (2018). Associations between screen time and lower psychological well-being among children and adolescents: Evidence from population-based study. Preventive Medicine Reports, 12, 271-283. https://doi.org/10.1016/j.pmedr.2018.10.003

Vandell, D. L., Simpkins, S. D. og Wegemer, C. M. (2019). Parenting and children's organized activities. Í M. H. Bornstein (ritstjóri ritraðar), Handbook of parenting: 5. bindi: The practice of parenting (3. útgáfa, bls. 347-379). Routledge.

WHO [World Health Organization]. (2012). Social determinants of health and well-being among young people: Health behaviour in school-aged children (HBSC) study: International report from the 2009/2010 survey. https://www.euro.who.int/_data/assets/pdf_file/0003/163857/Social-determinants-of-health-and-wellbeing-among-young-people.pdf

Sigrún Helgadóttir og Hrund Pórarins Ingudóttir. (2021).

„Núna eru allir einhvern veginn rosa uppteknir og pað er enginn sem svona heldur utan um krakkana“: Pörf á foreldrafræðslu: Sýn umsjónarkennara á miðstigi grunnskóla.

Netla - Veftímarit um uppeldi og menntun: Sérrit 2021 - Menntavika 2021.

Sótt af http://netla.hi.is/serrit/2021/menntavika_2021/03.pdf

DOI: https://doi.org/10.24270/serritnetla.2021.3 